\title{
TERRITORIAL ANALYSIS, DEVELOPMENT AND TECHNICAL ASSISTANCE AND RURAL EXTENSION FOR FAMILY FARMING
}

\author{
Marcela Almeida de Araujo ${ }^{1}$, Sergio Paganini Martins ${ }^{1}$, Gerd Sparovek ${ }^{1}$, Simone Beatriz Lima
} Ranieri $^{1}$, Adauto Brasilino Rocha Junior ${ }^{1}$

${ }^{1}$ University of São Paulo (USP-ESALQ), E-mail: marcela.araujo@usp.br, sergiopaganinimartins@gmail.com, gerd@usp.br, sblranieri@gmail.com, adautojunior@usp.br

\section{ABSTRACT}

In the last decade, significant changes in the national scenario have altered the productive and social dynamics of Family Agriculture (FA) and public policies for this public, such as Technical Assistance and Rural Extension (TARE), can play an important role in its strengthening. This study carried out a territorial analysis of the dynamics of access to TARE by FA in the last decade, through multiple data sources. The results show that the structuring of a new and efficient national TARE system must rely on: (i) state action, but not with the claim that they are the only source of such services; (ii) expansion of the performance of municipalities, where the participation of city halls may contribute to TARE becoming a quality service; (iii) continuous and quality training for extension workers; iv) creation of innovative financing mechanisms; and (v) promoting the integration of research and extension.

Keywords: Public policies, family agriculture, rural extension

\section{ANÁLISE TERRITORIAL, DESENVOLVIMENTO E ASSISTÊNCIA TÉCNICA E EXTENSÃO RURAL PARA A AGRICULTURA FAMILIAR}

\section{RESUMO}

$\mathrm{Na}$ última década, mudanças significativas no cenário nacional alteraram a dinâmica produtiva, social e as políticas públicas para a Agricultura Familiar (AF), como a Assistência Técnica e Extensão Rural (ATER), que pode desempenhar um importante papel no seu fortalecimento. Este estudo realizou uma análise territorial da dinâmica de acesso a ATER pela AF na última década, através de múltiplas fontes de dados. Os resultados mostram que a estruturação de um novo e eficiente sistema nacional de ATER deve contar com : (i) atuação estatal, mas não com a pretensão de que seja a fonte única de tais serviços; (ii) ampliação da atuação dos municípios, 
pois a participação das prefeituras poderá contribuir para que a ATER se torne um serviço mais local e de qualidade; (iii) uma capacitação contínua e de qualidade dos extensionistas; iv) criação de mecanismos inovadores de financiamento; e (v) promoção da integração da pesquisa e da extensão.

Palavras-chave: Políticas públicas, agricultura familiar, extensão rural

\section{INTRODUCTION}

A new Brazilian rural context is being developed in the last decade, with important changes regarding the productive and social picture of Family Agriculture (FA), featured in the Law $n^{\circ}$ 11.326/2006 (BRASIL, 2006), and the role of the Government in this process has been fundamental. A comparison between data from the last two Agricultural Censuses (2006 and 2017) indicates relative aging tendencies of the rural population, increase of income from activities apart from establishments and a clear process of land fragmentation, with loss of productive function in small establishments, simultaneously to the increase of mean area and productive concentration in medium and large establishments. At the same time FA does not grow in exploration area (opposite from the non-familiar agriculture) (IBGE, 2017), a recent study developed under coordination of the Family Agriculture Office (free-translation) (SEAD) shows that between 2006 and 2015 the gross added value by FA grew $80 \%$, following the agricultural sector growth as a whole. The added economic value growth in this period came from the better exploitation of the production factors, including the increase of productivity the work itself (SEAD/NEAD, 2017). Family Agriculture is among many production chains, such as commodities, production of basic feeding items and animal production (BUAINAIN \& GARCIA, 2013).

However, attached to its difficulties of organizations and strengthening on behalf of heterogeneity of cultures and production systems (GUILHOTO et al., 2007), FA gradually loses relative participation in vegetal production, including traditional chains such as bean, rice and wheat, at the same time it foresees an increase of FA competitiveness in animal production chains (swine, poultry, milk) and vegetal production of high added value, whose main example is coffee, in which Brazil is the biggest producer in the world and FA is related to almost half of this production (SEAD/NEAD, 2017).

It is in this context that new public policies for FA, with the ones turned to Technical Assistance and Rural Extension (TARE) among them, need to be aligned, in order to reinforce 
certain positive tendencies and curb those that may lead to social exclusion or feeding security impairment (FAO, 2001).

In this regard, TARE is an essential service for the process of sustainable rural development and for the Family Agriculture (FA) strengthening, contributing for social and productive inclusion of the ones excluded by the Brazilian agriculture modernization (ALVES \& ROCHA, 2010). Its origin in Brazil, in terms of laws, has as initial mark the creation of imperial institutes of agriculture, in 1859 and 1860, which held research attributions, agricultural education and information dissemination, which is typical of TARE. Since then, with many changes, the duty of the public operation in rural extension always have been present in many laws and as attribution of several government organizations linked to agriculture (PEIXOTO, 2008).

Nowadays, one of the biggest challenges regarding TARE in Brazil is the change of paradigm of a TARE guided by the primary production and by the grand participation of the public sphere for a broad and connected universe of familiar agriculturists. Many productive dynamics of FA, plotted in the last decades, require different focuses and levels of public participation on TARE. It is in the face of this observed tendencies that public policies for FA need to align, in a way to promote the positive tendencies and curb those that may lead to social exclusion and feeding security impairment.

This work aimed at conducting a territorial analysis of the access dynamics to TARE by FA in the last decade and of the service structure, personnel availability, assigned resources, and the public served among the main sources of TARE in Brazil, in order to provide supplies for discussions about the challenges of a new public policy of TARE for FA, considering the current Brazilian rural context, the "bottlenecks", strategies and main tendencies for this category of rural producers.

\section{MATERIAL AND METHODS}

The TARE dynamics for FA is discussed from the analysis of Agricultural Censuses from 2006 to 2017. The public TARE structure (statewide and municipal) is analyzed from data regarding available resources, structure, human capital, coverage, among others, made available by the Brazilian Association of State Entities of Technical Assistance and Rural Extension (ASBRAER) (free translation) and by the National Cities Confederation (CNM) (free translation). The approach adopted aimed at detailing and elucidating, based on 
territorial and spatial analysis, the main questions regarding TARE and the future of this public policy instrument for FA.

The research model adopted in the present analysis can be classified as "action research", once the research was conducted in close association with the theme and by cooperative/participative relation with the main actors involved (THIOLLENT, 2003). The structured data and their analysis were presented in a discussion panel hosted by SEAD, which was attended by the main actors related to TARE, with the SEAD team itself among them, members of ASBRAER, of CNM, of Brazilian Cooperatives Organization (BCO), of Brazilian Agricultural Research Corporation (EMBRAPA), of the Ministry of Finances, of Technical Assistance State Institutions, of National Confederation of Family Agriculture Rural Workers (CONTAG), and others.

As we are treating the analysis of a phenomenon constituted both by the economic dimension as by social and political dimensions, even if the research is based in the analysis of empirical data, the perspective of observational relativity characteristic of the "action research" is adopted as strategy for the critical approach and identification of possible strategies of the improvement of TARE policies, adding to the results discussion the main contributions of the actors involved in the dialogue. The developed discussions based the elaboration of this work with the main questions and guidelines for public policies of TARE in Brazil.

\section{RESULTS AND DISCUSSION}

\section{The available structure to operate the public TARE and its tendencies}

Analyzing the data about resources and personnel active in the public TARE in Brazil, it can be observed that there are state public institutions of TARE in each of the 27 units of the Federation. The more recent consolidated information, made available by ASBRAER on the existent structure, indicated, for 2018, the prediction of allocation of $\mathrm{R} \$ 2,80$ billion, considering the values assigned in the Annual Budget Laws (ABLs) to be implemented by the state organs of TARE. However, the history of resources application in TARE by the Federation units indicates that, in current values, there was a reduction of $19 \%$ between 2010 and 2018 and the extension workers has decreased in $26 \%$ in the same period, with only 11,716 extension workers hired in 2018 , which reflected in a reduction of approximately $15 \%$ in the number of cities served. 
Regarding public TARE, it can be observed, in a general way, as positive aspects that the state public institutions are present in every Federation units and there is significant capillarity in the Brazilian cities attendance, with coverage of $81 \%$, as a factor that can ease the implementations and monitoring of public policies at these locations that require the contact with the family agriculturist brokered by a TARE agent. On the other hand, among negative aspects, it can be observed the continuous reduction of operational capacity of these structures, set out by the reduction of $19 \%$ in the real values destined to TARE and of $26 \%$ in the extension workers in the last 8 years.

This scenario deserves attention because, more than the access to technical assistance aiming at the improvement of FA productive performance, TARE represents the possibility of its beneficiary public to access other public policies that can ensure their full citizenship. Rocha Junior et al. (2017), when analyzing the rural credit usage by Pronaf in 2014 , identified that $49.90 \%$ of the agriculturists that used Pronaf received technical assistance, while between those who did not use rural credit using the program, only $11.54 \%$ received TARE, pointing out the positive correlation between the access to both policies. The coordination of these policies is fundamental, considering that great part of the family agriculturists is in a social and economic vulnerability situation, and the viability of access to credit, to institutional markets and to information are the main means of stimulation to economic development of this public.

\section{The public TARE coverage}

Regarding the structure of service by state public TARE, it can be verified great capillarity. There are 4,022 service units in local (cities) context, which provides coverage of $81 \%$ of the Brazilian cities in 2018, when added the local (city) offices, the 181 advanced units, the 318 regional, the 78 qualification centers, and the 60 research units. Considering only local (city) offices, the coverage would be only $72 \%$ of the cities.

Besides the state structure, the Research of Basic City Information of the Brazilian Institute of Geography and Statistics (IBGE) (2017) reports that there are 2,522 municipal public organs acting in TARE, isolated or in partnership with state institutions. Currently, cities already represent the second biggest source of funding for TARE state organs (the resources volume via accords payment between states and cities is only surpassed by those originated from the State Treasury). Cities are stimulated to expand their actions in TARE because of animal health, which has been a 


\section{TERRITORIAL ANALYSIS, DEVELOPMENT AND TECHNICAL ASSISTANCE AND RURAL EXTENSION (ATER) FOR FAMILY FARMING}

crescent concern for many city halls, mainly on regions South, Southeast and Center-West, focused in stimulating their economy through the opening of markets for their agroindustries. Research from the CNM conducted in 2017 reports that 1,917 city halls are already benefited by Municipal Inspection Services (MIS), which indicates an increase of 44\% in 5 years (CNM, 2018). These city halls need to constitute TARE teams in order to act on the slaughter, on animal health control and on vaccination campaigns against diseases, overcoming commercial barriers, and improving the commercialization of the production of more than 8,000 agroindustries in the country. In the North region, stimulations factors for city actions in TARE may be different. With long distances and complex agriculturists attendance logistics, cities can be encouraged to enhance their participation in TARE by the constitution of their own teams, resulting in the creation of a local service structure with optimized costs. Besides that, results from other research conducted by CNM with data of few less than 2,000 city halls participants indicate that, even with regional differences, mainly regarding formation and remuneration, city halls have a mean of 4 professionals for TARE activities and present potential to expand their service coverage, being able to perform a relevant function in the development of Brazilian agriculture and livestock, once they have greater familiarity with specific local demands to each city, besides a bigger proximity with rural producers.

Since there is planning, formation and monitoring systematics previously stablished, this TARE national coverage structure can put their its agents in strategic position for the implementation and monitoring of any public policy in the rural context that depends on the contact of target public and agent. Besides that, the capillarity of the net enables the adequacy of regional strategies to local characteristics and needs.

\section{TARE tendencies in the last decade}

According with data from the last two Agricultural Censuses (2006 and 2017), there is stability in the added numbers of TARE receiving by FA, reaching approximately $20 \%$ of the establishments in the two periods. This stability demonstrates a structural and geographical accommodation of TARE turned to FA, whereas regions more consolidated in terms of agricultural and livestock production (South, Southeast and Center-West) are those where TARE remains more active, there is more Pronaf credit contracting and a stronger presence of cooperativism.

However, the stability shown in the added numbers hides microregional dynamics of growth and decrement of TARE for FA, explained by local variables (Figure 1). It is the local 
arrangement between productive systems and rural development that has been defining the TARE action - mainly governmental - and its capillarity.
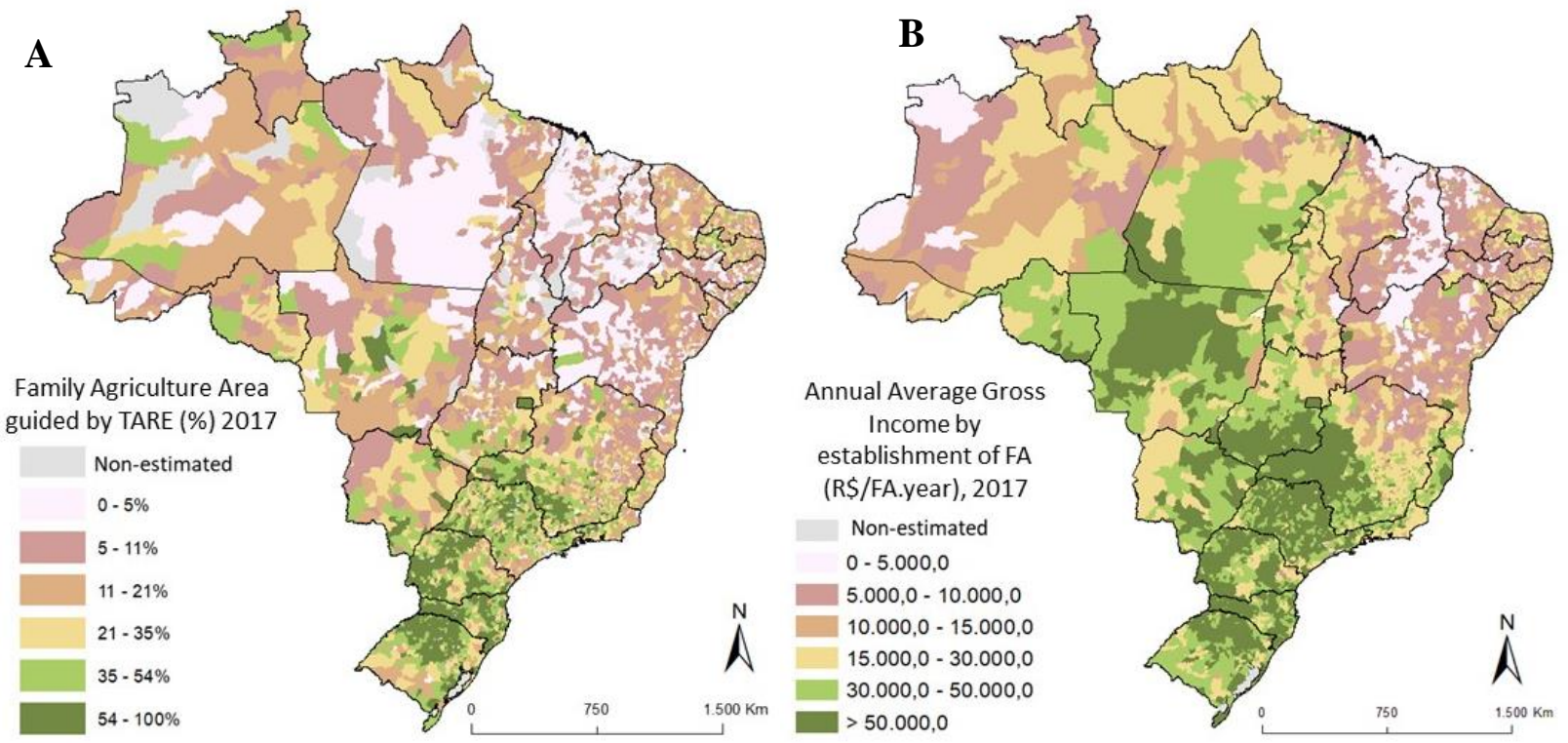

Figure 1A - Percentage of area of Family agriculturists guided by TARE in 2017.

Figure 1B - Annual income of FA establishments in 2017. Piracicaba, São Paulo State, Brazil, 2019. Source: Own elaboration

It can be observed a tendency of losing relative participation of governmental TARE and a gradual process of substitution of this for another (cooperative, own, integrating) sources. This substitution is more intense in more developed regions and with a more consolidated agriculture and livestock.

It can also be observed that TARE coverage for FA is low in cities with higher social vulnerability. The two Figure 1 maps elucidates the coincidence between the low TARE coverage (light-colored areas of map A) and the low income of cities (light-colored areas of map B). It is important to point out that Rocha Jr. et al. (2020), when analyzing econometrically the effect of receiving technical assistance on Brazilian family agriculturists in 2014, identified positive impact of $\mathrm{R} \$ 490,54$ in the monthly income of served producers, and also that the total increase of income in FA due to TARE represented only $15.8 \%$ of the total potential of income generation if all were served, pointing out the relevance of the technical assistance in the income generation in the field. 
The combined analysis of the aspects cited above suggests that TARE for FA, especially the governmental, is not being guided by a strategic territorial focus. In other words, the coverage of this service is insufficient to increase the family agriculturists income just in the poorest regions.

\section{How public TARE can advance:}

\section{(i) Count on stable budget}

The TARE execution by state organs implicates in the mobilization of a significant quantity of resources, considering its weakened finances. However, a significant parcel (almost 80\%) is compromised with personnel, remaining low availability to allocate in other essential items for service provision. The resources allocation by the federal government was crucial for the TARE renewal in the past decade, but in the last years it goes through great instability, with drastic reduction of the destinations to state organs.

The budget stability is essential for the definition of long-term strategies, yet being fundamental when considering the diversity of actors and the magnitude of federal, state, municipal resources and of other allocated institutions (human or financial terms).

\section{(ii) Instituting a TARE system}

An effective structure of a TARE system in national context will be capable of granting rationality to the existent framework, enabling the integrations of efforts from different institutions active in TARE: federal government, states, cities, private sector (cooperatives, technical assistance companies and non-governmental organizations), and others. This system must give special attention to TARE professionals, aiding its multidisciplinary formation so they can be prepared for knowledgement-transference activities. This professional profile is still poorly worked in agrarian studies graduation courses, which points to a necessity of changing the formation processes. The institutionalization of a TARE system and consequent career plans structuring in national level also has as indirect positive effect to attract youngsters for personnel fulfilling, which generates pression in the improvement of formation turned to TARE in universities.

\section{(iii) To regionalize actions to seize capillarity of the structure in long-term planning}

The institutionalization of TARE in a system, allied to budget stability, are the bases for reaching administrative and operational efficiency and consequently the development of 
regionalized strategies of long-term action adequate to the reality of each location. The development of strategies depends, by its turn, on studies based in territorial analysis which can take in account the multiplicity of factors and determinant processes of rural dynamics in its environmental, social and economic aspects.

(iv) To suit the new productive context of FA, preserving the protagonism and multidimensionality of public TARE

It is known that is important that the family agriculturist, even with a main activity in the property, has access to a basket of products that can allow the agriculturist to diversify activities in order to mitigate risks and improve income. Besides that, a specialized TARE demands very specific training directed to each productive activity of the family establishment, which public TARE is not always prepared to do. On the other side, the existence of a TARE that focus on management, long-term planning and socioenvironmental aspects that extrapolate the productive function of the establishment.

(v) To monitor and ease the service provision from the use of tools to digital systems

The biggest TARE current fortress, its capillarity, depends, for its good utilization, on adequate material and structural supplies (physical or human resources). Once satisfied these basic conditions, it is positive to invest on development of digital tools of service provision monitoring and efficiency indicators generations, which can favor specific training and the exchange of technical information in national collaboration nets at the same time.

\section{A new emphasis for TARE directed to FA:}

Besides the public TARE adjustments previously mentioned, it is necessary an adequacy analysis between family agriculturist profile, productive chain and regional characteristics, attributing the proper emphasis to the environmental question, in a way to give more accurate directions of TARE, both public and from another sources (private and shared).

A new emphasis for TARE directed to FA must consider tendencies observed in the last decade regarding this diversified public, with three turn points being highlighted in the TARE focus: (i) diversification with specialization; (ii) observe the different dynamics of FA; (iii) attention to the key-role of livestock. 


\section{(i) Diversification with specialization}

The FA heterogeneity described in the introductory section points at the necessity of adjusting the service provision for a public more and more diversified. In front of this profile diversities of FA, the concept of "diversification with specialization" is the key point to the conception of a new emphasis for the TARE directed to this public. This concept implicates in assuming that each FA establishment can adjust itself to one or more productive dynamics preserving its diversified and multifunctional characteristic, which was already shown as base for the generation of income and mitigation of risk in small areas.

The "diversification with specialization" demands a "core" TARE, preferably of public origin, linked to a results monitoring system that focus the establishment global management and that is capable inclusively of guiding the access to other specialized TARE sources, dedicated to different economic activities of the family agriculturist. Thus, the TARE multidimensional character is preserved in its economic, social and environmental action, aligned to the new challenges of FA productive insertion.

\section{(ii) TARE with different point-of-view for different FA dynamics}

The data analysis and projections for FA conducted in the present study enabled the identification of six main different productive dynamics, with different TARE approaches: (i) commodities (soy and maize); (ii) livestock integrated to industry (pig farming and poultry); (iii) specialized cultures (horticulture, fruit growing, coffee); (iv) beef cattle; (v) milk agriculture; and (vi) productive inclusion.

Each dynamic has its own spatial distribution and its specifications, with higher or lower levels of dependence on the public TARE. In the case of commodities, the production systems are based in technological packs already established and TARE is generally provided by supplies retailers and exporting companies.

In the livestock integrated to industry, assistance demands specific knowledge of the production system and is provided by technicians of the integrating company. In the case of specialized cultures, production can be very diversified in relation to the number of species cultivated, and TARE is specialized and frequently hired by the agriculturists. In beef cattle and milk farming, by their turn, the most present TARE is the public and sometimes the private, hired 
directly by the producers. In the case of productive inclusion, which includes family agriculturists who does not fit in the other dynamics, there is great diversity regarding production, low profitability, and there is no technological standards stablished, which turns the public TARE the main source of assistance for these agriculturists. With the objective of clarifying these differences, there were classified the main approaches of TARE for these different productive dynamics (

Na pecuária integrada à indústria, a assistência demanda conhecimentos específicos do sistema de produção e é prestada por técnicos da empresa integradora. No caso das culturas especializadas, a produção pode ser bastante diversificada com relação ao número de espécies cultivadas, a ATER é especializada e frequentemente contratada pelos agricultores. Nas pecuárias de corte e de leite, por sua vez, a ATER mais presente é a pública e algumas vezes a privada, contratada diretamente pelos produtores. No caso da inclusão produtiva, a qual inclui agricultores familiares que não se enquadram nas demais dinâmicas, existe grande diversidade com relação à produção, baixa rentabilidade, e não há um padrão tecnológico estabelecido, o que torna a ATER pública a principal fonte de assistência para esses agricultores. Com o objetivo de esclarecer tais diferenças, foram classificados os principais enfoques da ATER para essas diferentes dinâmicas produtivas (Table 1).

Table 1. TARE specifications for productive dynamics of FA

\begin{tabular}{|c|c|c|c|c|c|c|}
\hline \multicolumn{7}{|c|}{ TARE APPROACH BY PRODUCTIVE DYNAMIC TYPE } \\
\hline $\begin{array}{l}\text { Action approach of } \\
\text { TARE to FA }\end{array}$ & $\begin{array}{l}\text { Productive } \\
\text { inclusion }\end{array}$ & $\begin{array}{l}\text { Beef cattle } \\
\text { breeding }\end{array}$ & $\begin{array}{l}\text { Milk } \\
\text { farming }\end{array}$ & $\begin{array}{l}\text { Specialized } \\
\text { (hortifruti + } \\
\text { coffee) }\end{array}$ & Commodities & $\begin{array}{l}\text { Agriculture } \\
\text { integrated to } \\
\text { industry }\end{array}$ \\
\hline $\begin{array}{l}\text { Access to credit, } \\
\text { agricultural insurance and } \\
\text { other public policies }\end{array}$ & $+1+$ & $H+$ & $+H$ & $H+$ & $+1+$ & + \\
\hline Field technical support & $+1+$ & $+1+$ & $+H$ & $+H$ & $+1+$ & $+\mathrm{H}$ \\
\hline $\begin{array}{l}\text { Financial and management } \\
\text { organization }\end{array}$ & $+1+$ & + & $H$ & + & + & + \\
\hline Commercialization & + & + & + & $H+$ & + & $\bullet$ \\
\hline $\begin{array}{l}\text { Local and regional } \\
\text { integration of producers } \\
\text { (cooperativism) }\end{array}$ & + & - & $H+$ & H+ & H & $H+$ \\
\hline
\end{tabular}


Source: Own elaboration. *Also includes irrigated fruit growing and aquaculture

It can be observed that the main public of governamental TARE are the family agriculturists that fit in the dynamics of productive inclusion and beef cattle and milk farmings. When analyzing data from the Agricultural Census of 2017, for example, it can be identified that governmental TARE accounts for $60.6 \%$ of the total attendances among Pronaf users from group B, the ones that has annual income up to R\$23,000 (IBGE, 2017). This behavior can be observed in Figure 2.

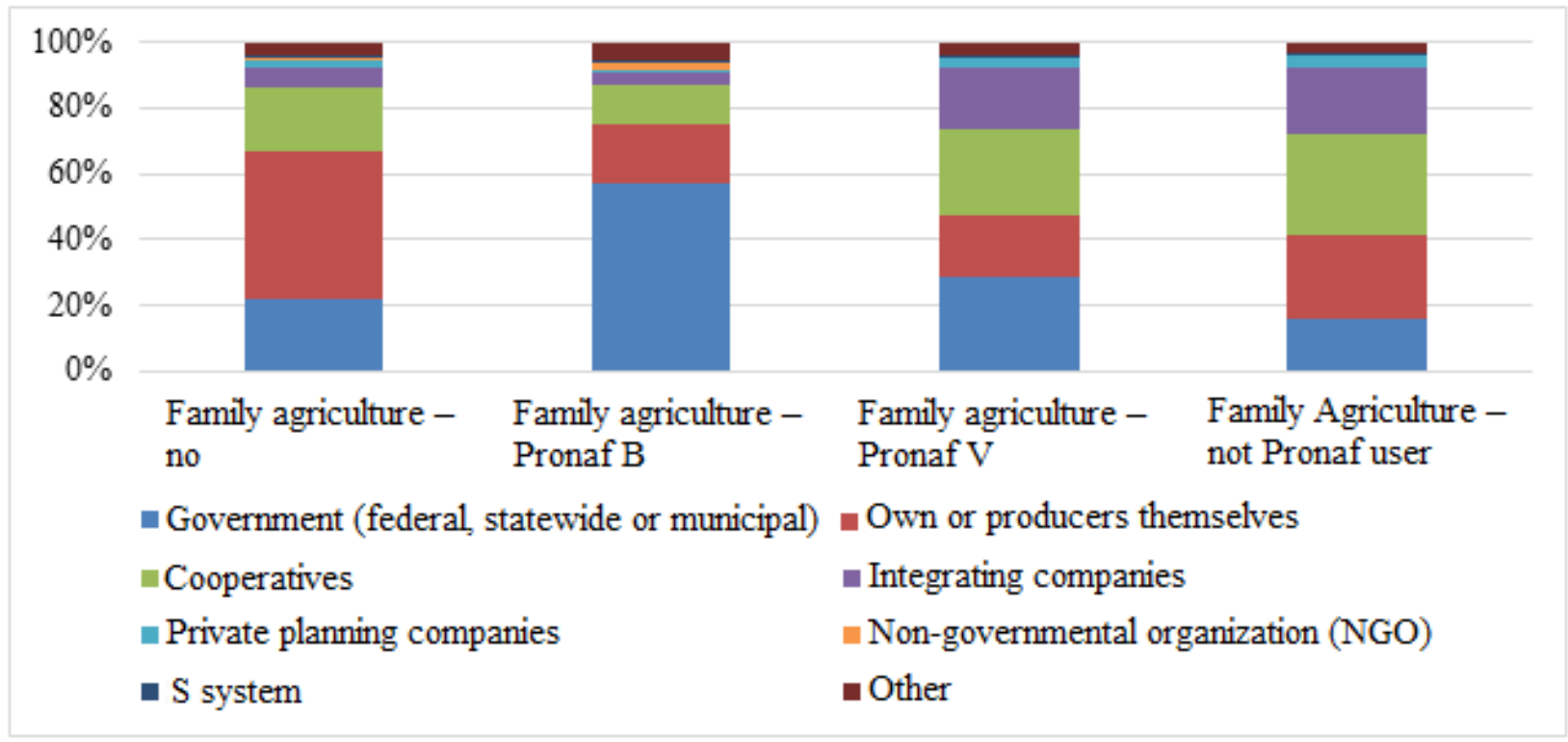

Figura 2. TARE sources for different agriculturists profiles. Source: Own elaboration based on data from the Agricultural Census of 2017 (IBGE, 2017).

For the rest of publics, however, there is access to alternative and more specialized sources of TARE. The main approaches of public TARE for these categories of family agriculturists are access to credit, to agricultural insurance and to other public policies, besides the field technical support. The role of the public extension workers as agents situated in the frontline is fundamental, for public FA strengthening policies and productive inclusion policies has as main target family agriculturists in poorer conditions, which are just those little integrated to the market, with low income and that has bigger difficulties in searching alternative sources of assistance and information. Thus, without adequate orientation, this public will hardly access the public policies of FA promotion. The FAs that work with artisanal fishing are also included in this group. 
(iii) The key role of livestock for FA

The retrospective analysis as well as the projection of economic scenarios for family agriculture demonstrates that there is a consolidated tendency in the FA gaining relative participation in chains of animal production (SEAD/NEAD, 2017). This role was carried out until the moment not only by the milk chains, historically linked to FA by its demand in labor, daily dedication and guarantee of monthly income, but also by the chains of production integrated to industries of chicken and swine.

By its turn, the FA are covered by pastures and dedicated to livestock of small and big ruminants is approximately double the size of the area destined to agriculture. Figure 3 clears out the great territorial importance of this land use for FA: in $80 \%$ of the Brazilian cities, pasture is the main use of land in FA and it is estimated that 1.3 million of establishments has livestock as main economic activity. Besides that, pastures, and consequently, the presence of cattle culture, is present from the northeastern Semiarid to the southern Pampas, in the most diverse biophysical and socioeconomic conditions.

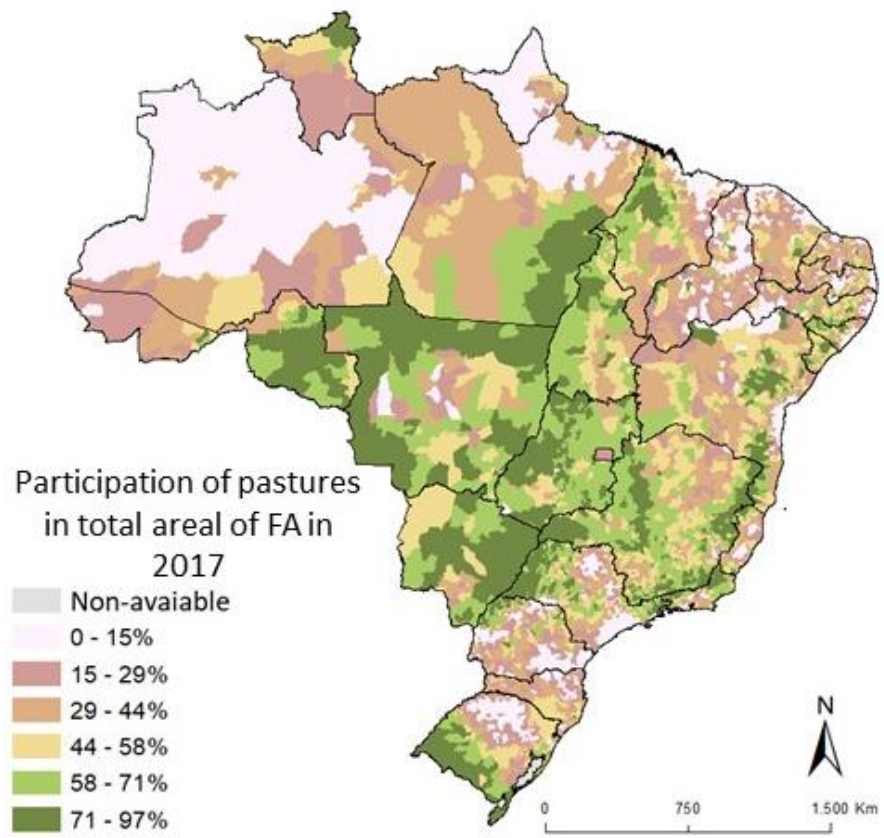

Figura 3. Participation of pastures in total areal of Family Agriculture in 2017. Source: Own elaboration based on data from the Agricultural Census (2017).

The huge territorial coverage of livestock involves the spatial overlap with areas of great social vulnerability, which places this sector as strategic for TARE action. Livestock has enormous 
margin for technical investment in systems adaptable to almost any type of condition. Even then, more than $60 \%$ of the total Pronaf for livestock is destined only to the "cattle purchasing" (SICOR, 2018), which creates opportunities for its link to TARE in programs with more attractive taxes

Still in this context there is the articulation of specific demands from animal protein industries for livestock of FA. These articulations must involve the construction of both subsidies punctually stablished (such as exonerations in the format of Social Biofuel Stamp), and also the satisfaction of FA for requirements related to animal well-being, such as the mandatory percentage of cage-free system in the egg production.

In all of the cases, the TARE, the supplies system (including animals) and the acquisition of the final product must be guaranteed, in a system integrated with transparency in the cost formation. This process is essentially of transversal articulation, because it depends on an understanding between the Ministry of Agriculture, Livestock and Supply (MAPA) and the Ministry of Treasury (MT), besides the key actors in the industry of animal proteins, so it can be aligned with an achievable proposal.

\section{CONCLUSION}

The set of information and reflections developed in this study allows to conclude that the structuring of a new and efficient national TARE system, with budget stability, must be fundamentally guided with state action, but not with the pretension of the Government being the only source of these services, but a manager and articulator of already existing tendencies. In this sense, it can be noted the following challenges and strategic action, which must be associated with the main aspects previously cited.

The cities already have a relevant participation in TAREA, but this participation can be expanded and qualified against the integrations of this TARE system entities, constituting their own teams, which, with capacitation actions and an effective articulation with federal and state spheres, can have decisive action in the local agricultural dynamics. The participation of city hall can contribute to TARE turning into a quality service, more and more local, since it is exploited in order to structure their teams counting on the planning support, formation and knowledge, methodology, financial stimulation, and a monitoring and evaluating system for the reached results.

A national TARE system requires special attention with its professional profiles. Besides the capacity of acting in a participative way with the benefited public, these must have the capacity 
of managing social processes and interaction ability, learning and adaptation. Initiatives turned to the practical capacitation of newly graduates in the agrarian studies in extension, for example, the residence in agricultural engineering, are still embryonic, punctual and care of more stimulation and reaching, so they can be put as option for specialization of these professionals as extension workers.

A TARE system, considered in its integrity, presents necessities of financing that overcomes the exclusive use of public resources and stimulates the creations of arrangements that can lead to the input of resources originating from diverse and alternative sources. Maybe the guideline of orientating the search for financing sources for an extensive TARE passes through creation of a sectorial fund, gathering not only governmental resources, but other resources originating from the gains provided by the TARE itself, and that they can be growing in as far as the service is capable of expanding the benefits to a higher number of agriculturists. Anater itself is an agency that will only consolidate itself as important actor in the context of TARE policy, as long as it is capable of counting on permanent source of resources, as occurred in the majority of cases of agencies. The resources thus obtained would be destined to direct actions of TARE, to the professional formation of extension workers, to the work infrastructure, to mass media, as well as to monitoring and evaluating actions, increasing the quality of services provided by the institutions.

The mechanisms to provide better integration between research and rural extension are multiple, and may include the coordination by the same ministry, the definition of other coordination instruments, the personnel interchange, or the cooperation between institutions. In this sense, it is worth to remember the Embrapa relevance in this integration process. Although the roles of research and development being attributed to the institution, it is important to improve the interchange mechanisms between the demands of the family agriculturist and the conducted researches, as well as the diffusion of the solution developed and strengthening of intern initiatives of technology transfer, as in the case of project Balde Cheio (EMBRAPA, 2011).

The bigger competitiveness of family agriculture requires the expansion of its acess to innovation, that for occurring needs stimulation such as the structuring of a national net of TARE, with the participation of researchers, extension workers and producers, endowed of instruments (platform) of availability and knowledge management, capable of fostering the auto organization, the interchange and the constant learning. This platform can provide better understanding of deficiencies in the process of learning, speed up the providing of answers and accelerate the 
generation and transference of technologies to those interested, in direction to more sustainable practices.

\section{ACKNOWLEDGEMENTS}

To the Public Policies Group (GPP/Esalq), to the Foundation of Agrarian Studies Luiz de Queiroz (Fealq), to Food and Agriculture Organization (FAO), and to the Ministry of Agriculture, Livestock and Supply (MAPA), which enabled the conduction of the present work through the Technical Cooperation Project (|PCT UTF/BRA/083/BRA). The present work was conducted with the support of CAPES, Financing Code 001.

\section{REFERENCES}

ALVES, E.; ROCHA, D.P., 2010. Ganhar tempo é possível? In: GASQUES, J.G.; VIEIRA. A Agricultura Brasileira Desempenho, Desafios e Perspectivas. Brasília. Available at: $</ /$ www.ipea.gov.br/portal/images/stories/PDFs/livros/livros/Livro_agriculturabrasileira.pdf $>$. Accessed on: Dec. 10, 2018.

ASBRAER. Associação Brasileira das Entidades Estaduais de Assistência Técnica e Extensão Rural, 2018. Proposta para a Assistência Técnica e Extensão Rural do Brasil.

Available at: <https://www.asbraer.org.br/media/attachments/2018/06/18/apresentacao.pdf>. Accessed on: Dec. 18, 2018.

BRASIL. 1991. Decreto $\mathbf{n}^{\circ} \mathbf{2 4 2}$ de 25 de outubro de 1991. Dispõe sobre a transferência de bens, haveres e contencioso judicial da Empresa Brasileira de Assistência Técnica e Extensão Rural, EMBRATER, em liquidação. Available at: <http://www.planalto.gov.br/ccivil_03/decreto/1990-1994/D242.htm.> Accessed on: Nov. 5, 2018.

BRASIL. Ministério de Desenvolvimento Agrário, 2004. Política Nacional de Assistência Técnica e Extensão Rural. Brasília. Available at: http://www.mda.gov.br/sitemda/sites/sitemda/files/user_arquivos_64/Pnater.pdf. Accessed on: Nov. 21, 2018

BRASIL. 2006. Lei 11.326. Diário Oficial da União, Brasília, v. 25, 2006.

BRASIL. 2009. Lei No 11.947. Diário Oficial da União, Brasília, 2009.

IBGE. Instituto Brasileiro de Geografia e Estatística, 2017. Censo Agropecuário. Available at: <https://sidra.ibge.gov.br/pesquisa/censo-agropecuario/censo-agropecuario-2017>. Accessed on: Jan. 01, 2019.

BUAINAIN, A. M.; GARCIA, J. R., 2013. Os pequenos produtores rurais mais pobres ainda tem alguma chance como agricultores? In: A pequena produção rural e as tendências do desenvolvimento agrário brasileiro: Ganhar tempo é possível?. Brasília. Available at: <https://www.researchgate.net/profile/Jose_Eustaquio_Vieira_Filho/publication/263697445_ Distribuicao_produtiva_e_tecnologica_dos_estabelecimentos_agropecuarios_de_menor_port e_e_gestao_familiar_no_Brasil/links/0deec53bafbd33b7dc000000/Distribuicao-produtiva-etecnologica-dos-estabelecimentos-agropecuarios-de-menor-porte-e-gestao-familiar-noBrasil.pdf\#page=31>. Accessed on: Nov. 28, 2018. 
CNM. Confederação Nacional dos Municípios., 2018 Estudo técnico: Análise dos Serviços de Inspeção Municipal (SIM). Brasília. Available at: <https://www.cnm.org.br/cms/biblioteca/An\%C3\%A1lise\%20dos\%20Servi\%C3\%A7os\%20 de\%20Inspe\%C3\%A7\%C3\%A3o\%20Municipal\%20(SIM)\%20-\%202018. Accessed on: Out. $25,2018$.

EMBRAPA. Empresa Brasileira de Pesquisa Agropecuária, 2011. Balde Cheio. Available at: <https://www.embrapa.br/balde-cheio>. Accessed on: Mar. 10, 2019.

DATER. Departamento de Assistência Técnica e Extensão Rural - PNUD/MDA, 2012. Relatório de consultoria técnica ao Projeto Fortalecimento da Agricultura Familiar. Brasília.

FAO. Food and Agriculture Organization of the United Nations, 2001.Agricultural and Rural Extension Worldwide: Options for Institutional Reform in Developing Countries. Available at: www.fao.org/3/a-y2709e.pdf Accessed on: Feb. 2, 2019.

FORNAZIER, A.; VIEIRA FILHO, J. E. R., 2012. Heterogeneidade estrutural no setor agropecuário brasileiro: Evidências a partir do censo agropecuário de 2006, Instituto de Pesquisa Econômica Aplicada (IPEA), Brasília, $\mathrm{n}^{\circ}$. 1708, p. 1-35.

GUILHOTO, J. J.; ICHIHARA, S. M.; SILVEIRA, F. G.; DINIZ, B. P. C.; AZZONI, C. R.; MOREIRA, G. R. C. 2007. A importância da agricultura familiar no Brasil e em seus estados. Brasília: NEAD.

PEIXOTO, M., 2008. Extensão rural no Brasil - uma abordagem histórica da legislação. Texto para discussão. Brasília, Available at: https://www12.senado.leg.br/publicacoes/estudoslegislativos/tipos-de-estudos/textos-para-discussao/td-48-extensao-rural-no-brasil-umaabordagem-historica-da-legislacao Accessed on: Feb. 5, 2019.

ROCHA JUNIOR, A. B.; CASSUCE, F. C. C.; CIRINO, J. F. Determinantes do uso do crédito rural do Pronaf em 2014. Revista de Política Agrícola, v. 26, n. 2, p. 100-114, 2017.

ROCHA JUNIOR, A. B.; SILVA, R. O.; PETERLE NETO, W.; RODRIGUES, C. T. Efeito da utilização de assistência técnica sobre a renda de produtores familiares do Brasil no ano de 2014. Revista de Economia e Sociologia Rural, v. 58, n. 2, 2020.

SEAD/NEAD. Secretaria Especial de Agricultura Familiar e do Desenvolvimento Agrário, 2017. PIB da agricultura familiar brasileira e instrumentos para o monitoramento da sua produção agropecuária. Projeto de Cooperação Técnica UTF/BRA/083/BRA, Brasília.

THIOLLENT, M. Metodologia da Pesquisa-Açãa, $12^{\circ}$ Edição. 2003.

VIEIRA, A. O.; LAFORGA, G.; MADEIROS, L. B. 2010.Modelos de extensão rural no Brasil e a Política Nacional de Assistência Técnica e Extensão Rural. PUBVET, Londrina, V. 4, N. 19, Ed. 124, Art. 842.

VIEIRA, A. O.; LAFORGA, G.; MADEIROS, L. B. 2018. Crédito rural. Available at: <www.mda.gov.br>. Accessed on: Dec. 20, 2018

SICOR. Sistema de Operações do Crédito Rural e do Proagro. Matriz de dados do crédito rural. Available at: 〈https://www.bcb.gov.br/en/\#!/n/SICOR〉. Accessed on: Dec. 10, 2018. 